\title{
火災加熱される木質部材内部の含水率計測手法の開発研究 DEVELOPMENT OF DYNAMIC MOISTURE CONTENT MEASUREMENT SYSTEM FOR WOODEN MEMBERS EXPOSED TO FIRE HEATING
}

\author{
鈴 木 達 朗*1, 長谷見 雄二*2, 上川大 輔*3, \\ 安井 昇 ${ }^{* 4}$, 加來千 紘*4, 鈴木 淳一*5 \\ Tatsuro SUZUKI, Yuji HASEMI, Daisuke KAMIKAWA, \\ Noboru YASUI, Chihiro KAKU and Jun-ichi SUZUKI
}

\begin{abstract}
A small sensor for the dynamic measurement of local moisture content within a wooden member exposed to fire heating is developed. The measurement is based on the unique dependence of electric resistance of wood on moisture content and temperature. Relationship between those is obtained by experiments for temperature between $20^{\circ} \mathrm{C}$ and $90^{\circ} \mathrm{C}$, and moisture content between $6.9 \%$ and $232.8 \%$ for Cryptomeria japonica, Larix leptolepis, Pseudotsuga menziesii and Zelkova serrata. Electric resistance is represented with temperature and moisture content for each tree species. The measurement is found to be most effective within the moisture content $10 \%$ - $30 \%$.
\end{abstract}

Keywords : Wooden Members, Heat and Water Transfer, Mechanical Property, Moisture Content Sensor, Electric Resistance 木質部材，熱水分移動，力学的性能，含水率計，電気抵抗

\section{1 はじめに}

木造による大規模建築・中高層建築を可能とする法整備や技術開 発が進められているが、建築物が大規模化・高層化すれば、個々の 部材への火災の影響が建物全体の安全性に及ぼす影響が大きくなり、 火災後の再利用の可能性を追求する必要も大きくなる。そのため、 火災加熱を受ける木造部材の力学的性能の予測評価は重要性を増し ていくであろう。

木材は、部材温度がセルロースの分解温度を超えれば炭化して力 学的に有効な断面が減少する 1),2) うえ、ヤング係数等の力学的性能 は温度・含水率の影響を受ける ${ }^{3), 4}$ ため、火災加熱で部材内部の温度 が上昇したり物質移動により含水率が変化したりすると、部材とし ての力学的性能は構造設計時に想定する常温時とは異なってくる可 能性がある。これらの影響は、樹種、製材や工業用木材等の別によ っても異なると考えられるが、これまで、炭化による有効断面の減 少が予想される場合は、燃えしろ設計において断面減少が一定の速 度で進むと仮定して、所定の時間の加熱後に必要な力学的性能を確 保している程度で、火災加熱されても炭化に至らない部分の力学的 性能の変化が十分に評価されてきたとは言い難い。

特に火災加熱時の力学的性能に対する水分の影響は、問題となる
のが $100^{\circ} \mathrm{C}$ 以下だけであるため最近までほとんど研究されてこなか った。Euro Code においても断面内部の物質移動は考慮されておら ず、木質部材の力学的性能は温度との関係として整理されているの みである5)。しかし、高温では常温時よりも含水率上昇による力学 的性能の低下が顕著で、例えば、飽水状態のスギの含水率を変化さ せずに温度を上昇させた場合、 $95^{\circ} \mathrm{C}$ でのヤング係数の常温時に対す る低下率は、全乾状態で $200^{\circ} \mathrm{C}$ まで上昇させた時の低下率と同程度 であることがわかっている 4)。また、木材中の水分の移動や相変化 は部材内の伝熱性状や熱分解性状にも影響し 6 , ,7)、含水率の上昇は 木造部材の炭化速度を低下させることが報告されている ${ }^{1,2), 8)}$ 。ら に、木材が内装材として用いられる場合には着火・燃焼発熱性状に 関する火災安全性に無視できない影響を及ぼす可能性もある。

火災加熱を受ける木材中の水分は、温度と含水率の勾配を駆動力 として移動する99)め加熱表面付近から比較的低温の非加熱面側に 水分が移動すると考えられ、木造部材の防耐火性能に対する含水率 の影響を系統的に把握するためには、水分移動を把握できるように する必要が大きい。そのためには、高温となる部材内部の局所的な 含水率の変化を計測できることが望ましいが、熱電対による温度測 定と同様に、簡便に含水率を計測できる汎用的な装置はなく、含水

\footnotetext{
*1 大成建設株技術センター 修士 (工学) (当時、早稲田大学)

*2 早稲田大学理工学術院 教授. 工博

*3 国立研究開発法人森林研究整備機構 博士 (工学)

*4 早稲田大学理工学術院総合研究所 招聘研究員・博士 (工学)

*5 国土技術政策総合研究所 博士 (工学)
}

Technology Center, Taisei Corp., M.Eng. (Formerly, Waseda Univ.)

Prof, Faculty of Science and Engineering Waseda Univ, DrEng.

Forestry Research and Management Organization, Ph.D.

Adjunct Researcher, RISE Waseda Univ., Ph.D.

National Institute for Land and Infrastructure Management, Ph.D. 
率の防耐火性能一の影響を把握する妨げとなっている。本研究では、 筆者らが開発した局所的な含水率の時間変化を計測でき、かつ加熱 実験時の高温にも耐え得る計測手法 10),11)について報告する。

\section{2 検討指針}

\section{1 局所的な含水率の計測手法}

時々刻々と变化する火災加熱時の木質部材内部の含水率を計測す るためには、局所的な含水率を計測でき、かつ非破壊の計測手法で ある必要がある。加熱直後に木材を細かく裁断し、それぞれを乾燥 させれば含水率分布を調べることが可能だが、ある瞬間の含水率分 布しか算出できず、火災加熱を受ける木質部材の含水率の時間変化 を把握することもできない。一方、非破壊で含水率を計測する手段 としては、木材に X 線を透過させその減衰から含水率を逆算する手 法があり、Fredlund はコーンカロリーメーターに X 線放出・検出 器を併設して、定常加熱下の含水率分布の変化を計測した事例を報 告している 6)。ただし、耐火炉等で非定常加熱時の含水率分布の変 化を把握するためには、装置の設置や耐熱性の確保等に大きな困難 がある。その他の非破壊で含水率を計測する手法としては、木材に 穿孔等を行わずに、木材表面に探知部を押し当てて誘電率から含水 率を逆算する手法 ${ }^{12)}$, 13 等があるが、厚み方向の分布は計測できない。

ところで、木材と同様に多孔質部材であるコンクリート内部の水 分移動に関しては、試験体に電極を埋設し、電気抵抗から加熱中の 局所的な含水率を逆算する計測手法が用いられている ${ }^{14)}$ 。木材内部 の電気抵抗も含水率と高い相関があること 15), 16)が知られており、木 材内部についても電気抵抗から局所的な含水率の時間変化が逆算で きる可能性があると考えた。本研究では、木材内部の任意の箇所に 電極を埋設し、電極から測定した電気抵抗から含水率を推定するこ とを試みる。

\section{2 電気抵抗による含水率計の開発指針}

計測装置は、電気抵抗により非破壊で部材内部の局所的な含水率 を計測するため、予め埋設した電極から電気抵抗を計測し、電気抵 抗と含水率の関係を表す校正曲線から含水率を逆算するものとした。 まず、木材中に埋設する電極は、局所的な含水率の変化を測定す るため小型である必要がある。それに適した測定法として、常温で の高含水率状態による腐朽のリスクを管理する目的で先端部のみが 電極となるように銅線を埋設し、電気抵抗から含水率を計測する装 置が開発されている ${ }^{15)}$ 。しかし、その計測装置は常温下の計測を前 提としており、高温下の実験で用いるには先端の電極から計測器ま で電気的絶縁と耐熱性を確保する必要がある。そこで本研究では、 文献 ${ }^{15)}$ の測定装置及び測定方法を、火災加熱を想定した実験で使用 できるように改良する。

次に、木材の常温時及び高温時の電気抵抗と含水率の関係を実験 により把握する。計測結果から回帰分析を行い、電気抵抗と温度か ら含水率を算出する校正曲線を導出し、常温・高温での電気抵抗と 含水率の関係に対する影響要因を検討する。また、常温時における 電気抵抗と含水率の関係は、含水率が高い場合、含水率の変化に対 する電気抵抗の変化が小さくなるため、誤差が増大寸ることが考え

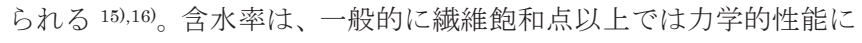
影響しないが、炭化速度や伝熱性状に対しては高含水率でも影響を 及ぼす 2),6 (8) ため、計測可能範囲と誤差について検討を行う。
文献 15)ではノルウェイスプルース( Norway spruce : 英名、全乾 密度 $0.393 \mathrm{~g} / \mathrm{cm}^{3}$ )を対象とし、常温時の校正曲線を誘導しているが、 電気抵抗と含水率の関係は樹種によって異なると予想されたため、 本研究では、大断面木質部材に一般的に用いられる針葉樹材として スギ、カラマツ及びベイマツに加え、大断面製材として用いられる ことの多い広葉樹材としてケヤキの計 4 種類を対象とした。ケヤキ については、大断面製材の乾燥は困難で伝統様式の建築物に使われ る場合は含水率が高いままである例も多くみられる8)。

\section{3 計測方法 \\ 3.1 電極の仕様}

\subsection{1 高温下での計測に向けた改良}

Fig. 1 に本研究の含水率計の仕様を示す。常温下の測定を想定し た文献 ${ }^{15)}$ の仕様を改良し、電極の設置個所から電気抵抗の測定装置 までを、電気的絶縁と耐熱性を確保して配線することを可能とした。

文献 ${ }^{15)}$ における基本的な計測手法は、先端 $1 \mathrm{~mm}$ のみが通電する ような電極を $10 \mathrm{~mm}$ 間隔で一対埋設しておき、電気抵抗を計測する ものである。先端のみを電極とするためのセンサーの設置方法とし て、木材に穴を空け、予め絶縁性のチューブを奥まで差しこんだ後 $1 \mathrm{~mm}$ 分引き上げ、シリンジで先端部に導電性の接着剂を注入、銅の 単線を挿入している 15 )。電気抵抗計測の結果、心材 ・辺材、早材 晚材、及び密度の違いが電気抵抗に影響しないことが報告されてお り 15)、本研究では電極間距離を文献 15) と同じ $10 \mathrm{~mm}$ とすることで、 それらの影響を考慮しないこととした。

高温となる耐火炉内で測定を可能にするため、本研究では文献 15) の仕様に対して 2 点の改良を行った。まず、配線の電気的な絶縁性 之耐熱性を確保するため、文献 15)の銅の単線を、市販のふつ素樹脂 及び ETFE で被覆されたニッケル単線(以下、絶縁導線と称する)に 置き換えた。次に、キャピラリーチューブは、文献 15)では木材表面 より突出しているが、本研究では試験体の表面や集成材のラミナ間 の配線を可能にするためキャピラリーチューブは木材表面位置で切 断するものとした。

また、高温時の含水率と電気抵抗の関係を調べるためには、試験 体を加熱した状態で電気抵抗を計測する必要がある。試験体は、水 を含浸させた後、加熱による水分移動の影響を抑えるため予め全面 をシリコンでシーリングを行った。熱電対を設置し恒温炉で目標の 温度に達するまで加熱した後、電気抵抗を計測するものとした。

なお、絶縁導線に用いる金属の電気抵抗も、温度上昇により変化 するが 17)、絶縁導線の金属の温度上昇による電気抵抗の変化を木材 と比べると最大でも $0.1 \%$ 以下であり、その影響は小さい注1)。

\section{1 .2 電極の仕様と埋設方法}

本研究の含水率計の設置方法を以下 i ) iv)に示す。電極の耐熱 温度は、キャピラリーチューブが $260^{\circ} \mathrm{C}$ 、絶縁導線及び接着剂が $150^{\circ} \mathrm{C}$ であるため、絶縁導線が $150^{\circ} \mathrm{C}$ 以下になるように配線を行う 必要がある。

i ）木材に所定の深さまで $\phi 1.6 \mathrm{~mm}$ の穴を 2 箇所、 $10 \mathrm{~mm}$ 間隔で空 ける。

ii）穿孔した穴より $1 \mathrm{~mm}$ 短く切断しておいたキャピラリーチュー ブを穴に挿入し、穴の先端 $1 \mathrm{~mm}$ 以外を絶縁する。 


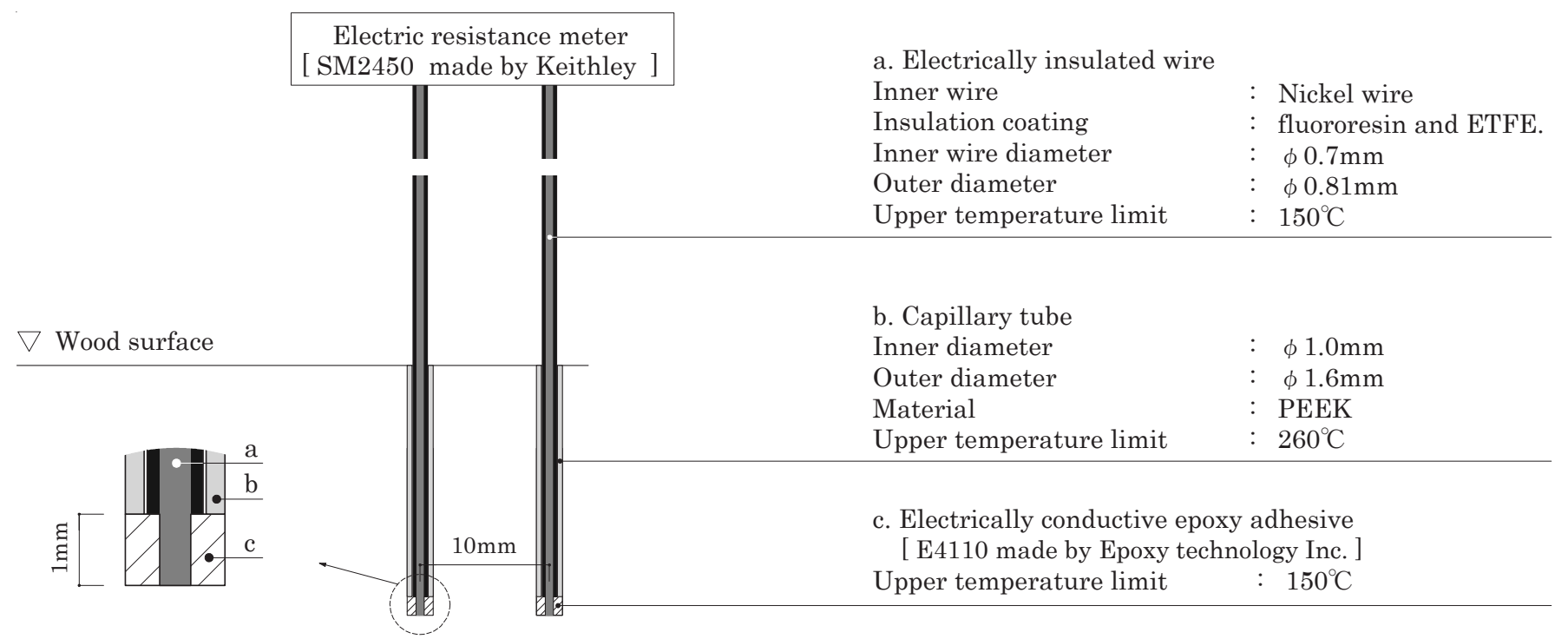

Fig.1 Specification of the proposed heat resistant moisture content sensor

iii）先端を導電部とし、後に挿入する絶縁電線を固定する目的で、 導電性の接着剤をシリンジを用いて穴の先端に注入する。

iv）先端をストリップした絶縁導線を穴の奥まで挿入し、接着剂の 硬化を待つ。(本研究で用いる接着剤の硬化は高温時ほど早くな

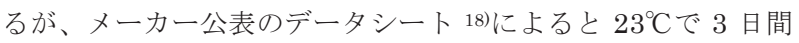
が必要である。)

\section{2 計測機と印加電圧}

電極から出た絶縁導線はデータロガーに接続して電圧の印加、及 び電気抵抗の計測を行う。木材は同じ極性で電圧を印加し続けると 時間経過とともに電気抵抗が漸増していく性質があることから 19)、 文献 ${ }^{15)}$ と同椂に、 0.5 秒間電圧を $2 \mathrm{~V}$ で印加し、次の 0.5 秒間は極性 を反転して $-2 \mathrm{~V}$ の電圧を印加することを繰り返すこととした。

また、印加電圧は木材中を流れる電流が微電流であることから、
計測精度を高めるためには印加電圧も高くしたいが、印加電圧が高 いと時間経過に対する電気抵抗の上昇も激しい 19)ため、文献 15 に従 い $2 \mathrm{~V}$ とした。

\section{3 電気抵抗の計測方法}

\subsection{1 試験体}

本研究では、多様な含水状態において電気抵抗を計測することを 目的とし、板状の試験体の長さ方向に含水率勾配をつけ、含水率と 電気抵抗の関係を把握する。試験体は、厚み $30 \mathrm{~mm}$ 、幅 $120 \mathrm{~mm}$ の 板材とし、Fig.2 に示寸長さの異なる試験体 A,B を用いた。含水率 勾配をつける手法として、試験体 $\mathrm{A}$ は長さ $600 \mathrm{~mm}$ のうち下部の $150 \mathrm{~mm}$ を $20^{\circ} \mathrm{C}$ 環境下で水に浸す。試験体 $\mathrm{B}$ は、試験体 $\mathrm{A}$ と比較 して高含水率の電気抵抗を計測するため、長さ $200 \mathrm{~mm}$ とし、片方 の小ロのみシリコンシーリングを施し、減圧加圧注水を行う。含水

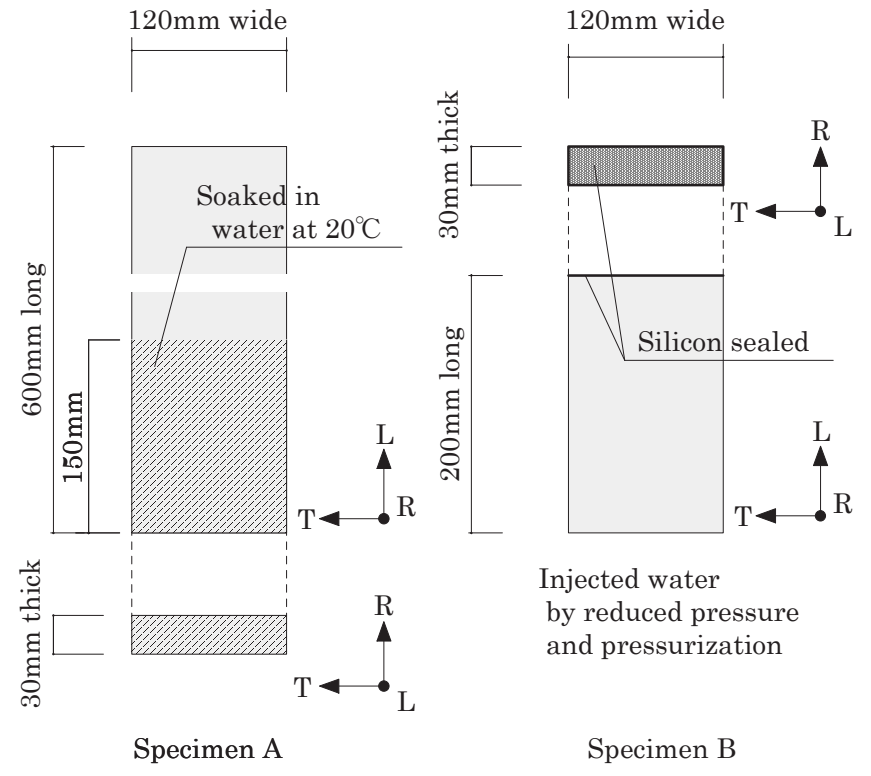

Fig.2 Specimens used for electric resistance measurement

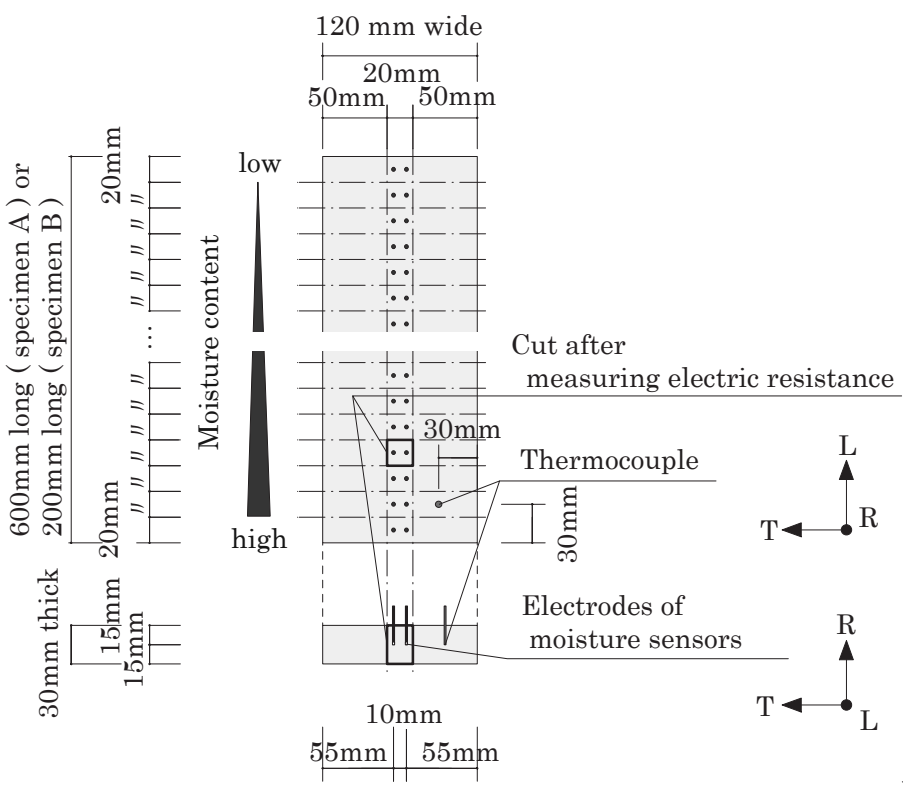

Fig.3 Layout of sensors (thermocouples and electrodes) and locations of post-measurement cutting of the specimen

L, R and T means Longitudinal, Radial and Tangential direction of wood in Fig.2 and 3 
率計は、Fig.3 に示すように含水率勾配を生じさせた試験体の長さ 方向に $20 \mathrm{~mm}$ 間隔で並べて設置することで、多様な含水状態におけ る電気抵抗を計測する。

樹種ごとの試験体 A,B の含水率を Table1 に示す。ただし、スギ は試験体 A で最大 $232.8 \%$ と十分に高い含水率が得られたため、試 験体 B は用いなかった。スギ以外の 3 樹種では、試験体 A,B をそれ ぞれ一体ずつ用いた。

試験体には Fig.3 の箇所に熱電対を設置し、内部温度を計測する。 試験体の内部温度が $20,50,70$ 及び $90^{\circ} \mathrm{C}$ の時に電気抵抗を計測する。 スギのみ $80^{\circ} \mathrm{C}$ にいても電気抵抗を計測している。

Table 1 Moisture content of specimens A and B

\begin{tabular}{lcccccc}
\multirow{2}{*}{\multicolumn{1}{c}{ Tree species }} & \multicolumn{4}{c}{ Misture Content[\%] } \\
\cline { 2 - 3 } & \multicolumn{3}{c}{ Specimen A } & & \multicolumn{2}{c}{ Specimen B } \\
\cline { 2 - 3 } Cryptomeria Japonica (スギ) & 66.0 & $6.9-232.8$ & & - & - \\
Larix leptolepis (カラマツ) & 19.9 & $8.8-59.4$ & & 38.7 & $17.5-71.8$ \\
Pseudotsuga menziesii (ベイマツ) & 21.0 & $9.5-74.7$ & & 43.0 & $21.0-76.7$ \\
Zelkova serrata (ケヤキ) & 22.5 & $8.5-63.9$ & & 47.1 & $22.1-68.6$ \\
\hline
\end{tabular}

\subsection{2 常温時及び高温時の電気抵抗計測}

加熱を行わない $20^{\circ} \mathrm{C}$ の試験体は、温度 $20^{\circ} \mathrm{C}$ 、相対湿度 $40 \%$ の室 内の中で電気抵抗を計測する。 $20^{\circ} \mathrm{C}$ 以外の加熱を行う試験体は、試 験体を目標の温度より $1^{\circ} \mathrm{C}$ 高く設置した恒温炉内に設置、加熱する。

Fig.3 の箇所に設置した熱電対の温度が目標の温度に達した時点 で、試験体全体が目標の温度に達したとみなし、電気抵抗を計測す る。本計測法による含水率の計測精度を評価するために、電気抵抗 を計測後、計測箇所近傍の幅及び長さ $20 \mathrm{~mm}$ 、高さ $30 \mathrm{~mm}$ の直方体 をそれぞれ切り出して質量を計測した後、 $105^{\circ} \mathrm{C}$ の恒温炉で乾燥さ せ、全乾法で含水率を算出して、電気抵抗から算出される含水率と 比較することとした。含水率計近傍の含水率は、直方体内部の含水 率分布は考慮せずに算出するものとした。

なお、試験体の加熱中及び切断時の水分の蒸発による断面内部の 含水率の変化を最小限にするため、試験体に熱電対及び含水率計を 取り付けた後に、表面を 6 面ともシリコンでシーリングし、加熱を 行った。また、切断から質量計測までの時間を極力短くするため、 シリコンが試験体に塗布されたまま質量を計測し、乾燥後にシリコ ンを剥がしその分の質量を差し引いた。また、試験体切断時の水分 の蒸発を最小限にするため、試験体の切断は水分の蒸発が激しいと 考えられる高含水率側から行い、順次質量を計測した。

\section{4 計測結果と考察}

\section{1 計測結果}

各樹種の温度ごとの含水率と電気抵抗の計測結果を Fig.4 7 に示 す。縦軸は電気抵抗の自然対数、横軸は含水率を表す。実験結果を 近似する実線、破線については 4.2 で述べる。含水率は、全乾質量 を分母とする（1)式を用いた。

$\mathrm{M}=\frac{\mathrm{W}_{\text {wet }}-\mathrm{W}_{\text {dry }}}{\mathrm{W}_{\text {dry }}} \times 100$

$\mathrm{M}:$ moisture content [\%]

$\mathrm{W}_{\text {wet }}$ : weight (wet) $[\mathrm{g}] \quad \mathrm{W}_{\mathrm{dry}}$ : weight (dry) [g]
試験体の平均全乾密度はスギ $0.334 \mathrm{~g} / \mathrm{cm}^{3}$ 、カラマツ $0.526 \mathrm{~g} / \mathrm{cm}^{3} 、$ ベイマツ $0.482 \mathrm{~g} / \mathrm{cm}^{3}$ 、ケヤキ $0.688 \mathrm{~g} / \mathrm{cm}^{3}$ であった。

いずれの樹種でも、含水率及び温度が高いほど電気抵抗が減少し た。ただし、ケヤキの含水率 $10 \sim 15 \%$ 付近では、 $70^{\circ} \mathrm{C}$ の電気抵抗の 計測值が $90^{\circ} \mathrm{C} の$ 電気抵抗の計測值に近づいた。

Fig.4 7 には、ノルウェイスプルースの $20^{\circ} \mathrm{C}$ での校正曲線 15)を一 点鎖線で併記している。ノルウェイスプルースと比較すると、スギ、 常温の含水率 $15 \%$ 以下の範囲を除いて、電気抵抗は本実験の方が低 い結果となった。電極間距離、電極先端の大きさ及び導電性接着剤 は同一である他、電気抵抗が計測された温度も $20^{\circ} \mathrm{C}$ と本研究と同一 のため、この違いは樹種によると考えられる。

\section{2 回帰分析による校正曲線の誘導}

電気抵抗及び温度から含水率を逆算可能にするため、実験結果か ら回帰分析を行い、校正曲線を導出する。本研究で電気抵抗を計測 した温度は 4 条件のみだが、火災加熱時の木質部材内部で温度は連 続的に変化するため、校正曲線は温度ごとに表すのではなく、温度 及び含水率の連続した関数として表す必要がある。そのため、まず 温度ごとに回帰分析を行ったのちに、その回帰式の温度依存性を分 析する。

\section{(1) 計測温度ごとの回帰分析}

温度ごとの回帰分析にあたっては、文献 15)に従い(2)式を想定した。 回帰分析の際には、(3)式のように含水量を無次元で表した比(以下、 含水比と称する)を用いた。Fig.4 7 には、温度ごとの回帰分析結果 を実線で示している。

$\ln (\mathrm{R})=\mathrm{a}+\mathrm{b} \cdot \mathrm{u}+\mathrm{c} \cdot \exp (\mathrm{d} \cdot \mathrm{u})$

where $\mathrm{b} \leqq 0$

$\mathrm{R}$ : electric resistance $[\Omega]$

a, b, c : constant $[\Omega]$

$\mathrm{d}:$ dimensionless constant $[-]$

$\mathrm{u}=\frac{\mathrm{w}_{\mathrm{wet}}-\mathrm{w}_{\mathrm{dry}}}{\mathrm{w}_{\mathrm{dry}}}$

$\mathrm{u}$ : moisture content ratio

( dimensionless moisture ratio ) [-]

\section{（2）温度依存性を考慮した校正曲線の一般化}

次に、校正曲線を温度及び含水率の関数として表すため、(2)式に おける係数 a,b,c,d を温度の一次関数とし、係数 a,b,c,d が変化した 際に電気抵抗を最も適切に表せるように再度回帰分析を行った。回 帰分析により得た、係数 a,b,c,d と温度 $\mathrm{T}\left[{ }^{\circ} \mathrm{C}\right]$ の関数を Table2 に示 す。Fig.4 7 には、Table2 に示寸係数 a,b,c,d を(2)式に代入した校 正曲線を点線で示し、括弧内にそれらの決定係数( $\mathrm{R}$ 二乗值)を併記 している。

ただし、係数 $\mathrm{b}$ が正の值をとると、含水率の上昇に伴い $\ln (\mathrm{R})$ は 横ばいになった後増加し、重解となってしまうため、必ず $100^{\circ} \mathrm{C}$ 以 下で 0 以下となるものとした。スギでは温度上昇によって係数 $\mathrm{b}$

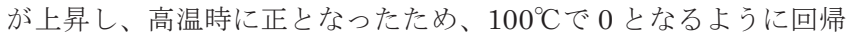
分析を行った。ケヤキでは温度上昇によって係数 b が低下してい くが切片が正となったため、切片を 0 として回帰分析を行った。 


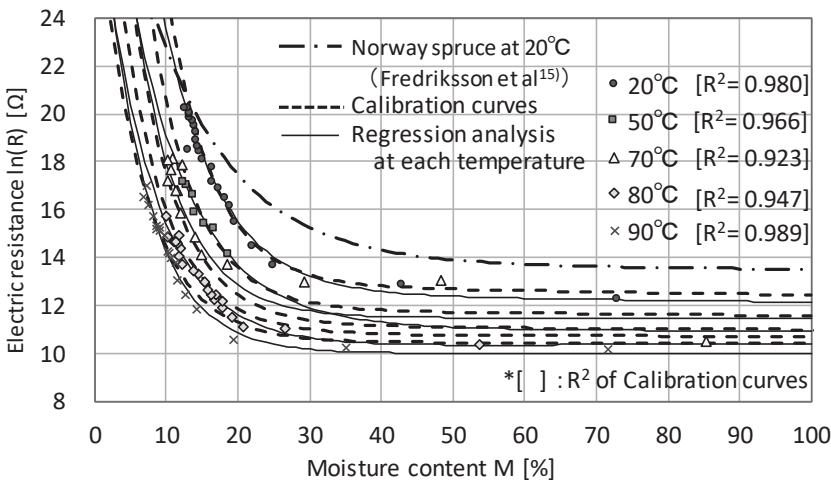

Fig.4 Calibration curve (Cryptomeria japonica, スギ)

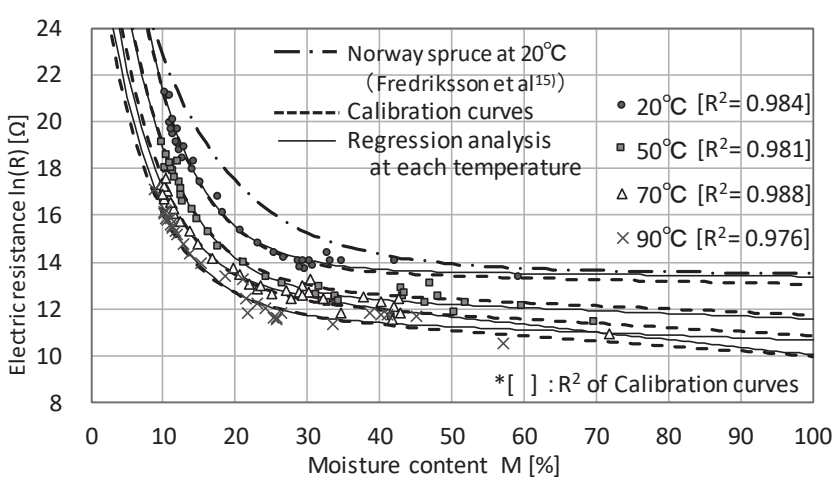

Fig.5 Calibration curve (Larix leptolepis，カラマツ)

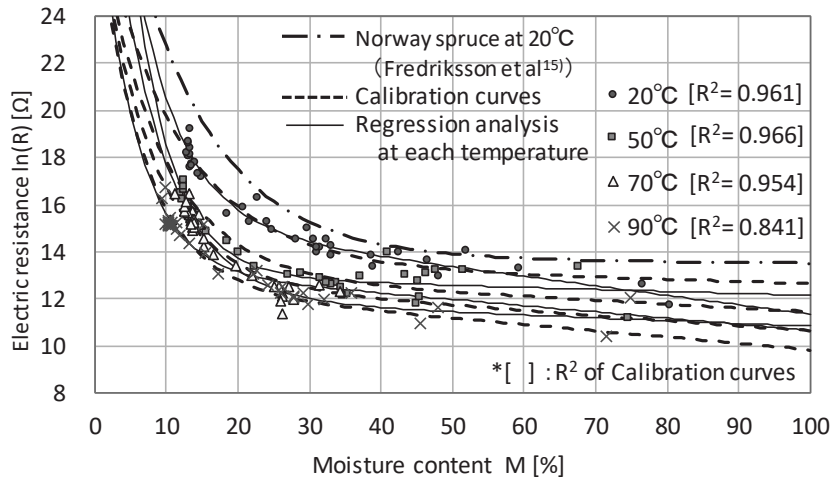

Fig.6 Calibration curve (Pseudotsuga menziesii, ベイマッ)

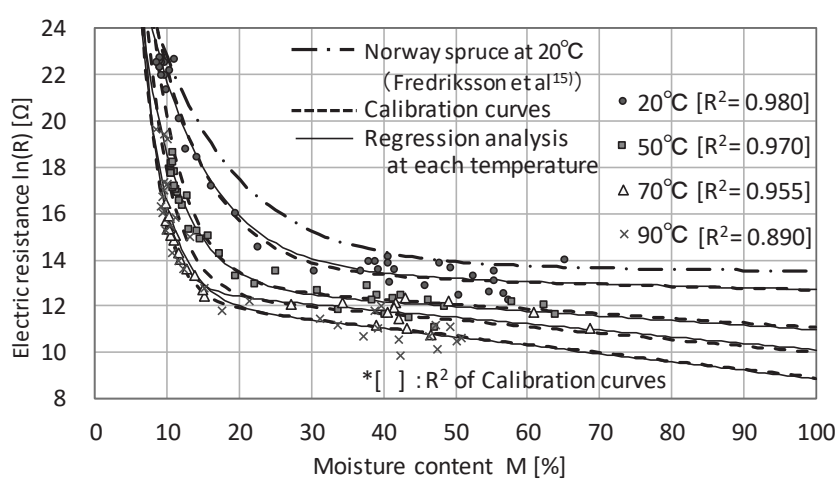

Fig.7 Calibration curve (Zelkova serrata,ケヤキ)

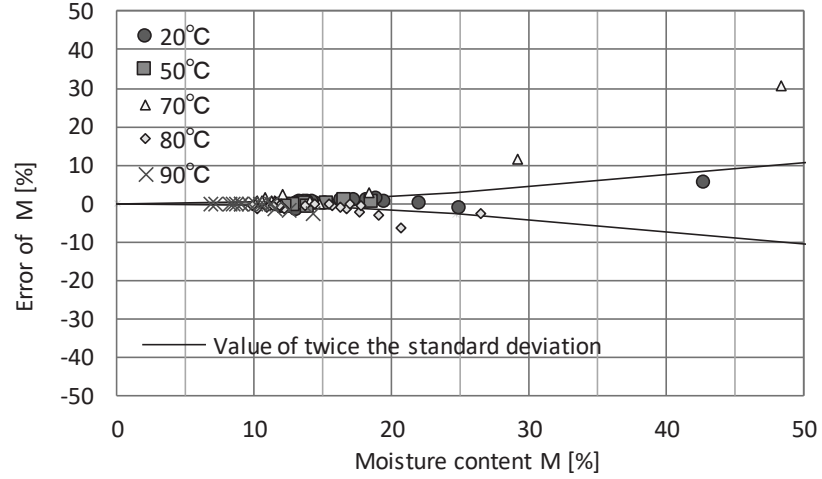

Fig.8 Error of Calibration curve (Cryptomeria japonica, スギ)

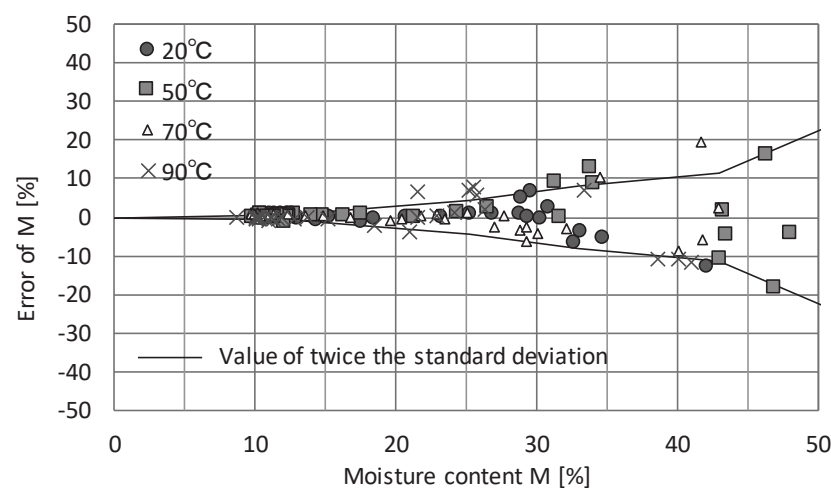

Fig.9 Error of Calibration curve (Larix leptolepis，カラマツ)

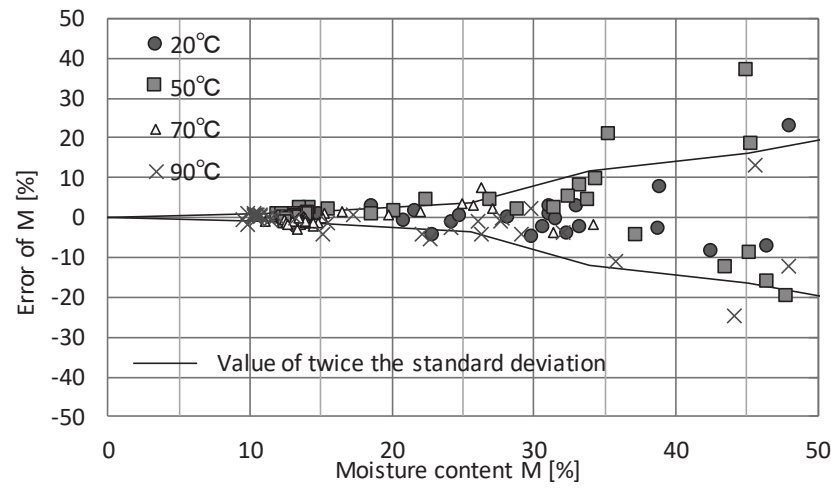

Fig.10 Error of Calibration curve (Pseudotsuga menziesii,ベイマッ)

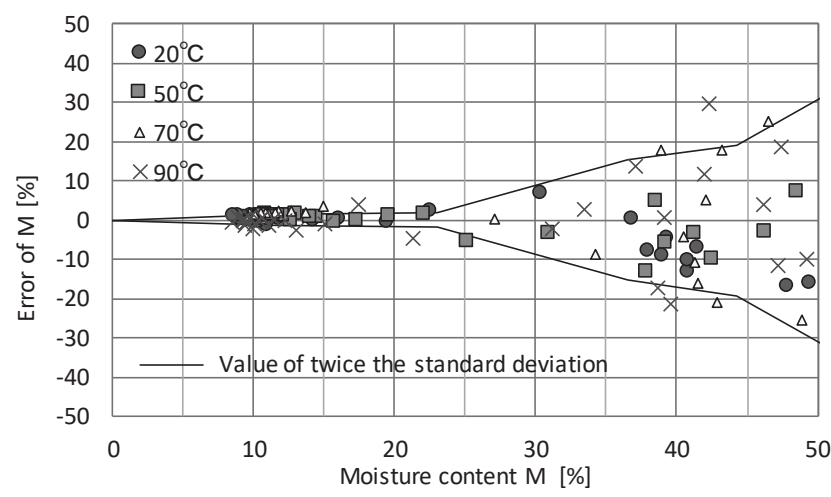

Fig.11 Error of Calibration curve (Zelkova serrata,ケヤキ) 
Table 2 Constants a,b,c,d in formula (2) and (4)

\begin{tabular}{l} 
Cryptomeria Japonica（スギ) \\
\hline $\mathrm{a}=-0.034573 \cdot \mathrm{T}+13.60$ \\
$\mathrm{~b}=0.005882 \cdot \mathrm{T}-0.5882$ \\
$\mathrm{c}=-0.610560 \cdot \mathrm{T}+73.912$ \\
$\mathrm{~d}=0.008439 \cdot \mathrm{T}-16.475$
\end{tabular}

Larix leptolepis（カラマツ) $\mathrm{a}=-0.022509 \cdot \mathrm{T}+14.18$

$\mathrm{b}=-0.021199 \cdot \mathrm{T}-0.2484$

$\mathrm{c}=-0.186304 \cdot \mathrm{T}+33.947$

$\mathrm{d}=-0.007789 \cdot \mathrm{T}-13.710$

\begin{tabular}{cl}
\multicolumn{3}{c}{ Pseudotsuga menziesii (ベイマツ) } \\
\hline $\mathrm{a}=-0.013924$ & $\cdot \mathrm{T}+13.76$ \\
$\mathrm{~b}=-0.026222$ & $\cdot \mathrm{T}-0.3084$ \\
$\mathrm{c}=0.004951$ & $\cdot \mathrm{T}+15.423$ \\
$\mathrm{~d}=-0.085326$ & $\cdot \mathrm{T}-7.241$
\end{tabular}

Zelkova serrata（ケヤキ)

$\mathrm{a}=-0.014081 \cdot \mathrm{T}+13.78$

$\mathrm{b}=-0.040137 \cdot \mathrm{T}$

$\mathrm{c}=1.200793 \cdot \mathrm{T}+8.704$

$\mathrm{d}=-0.313521 \cdot \mathrm{T}-6.892$

$\mathrm{T}$ : Temperature $\left[{ }^{\circ} \mathrm{C}\right]$

Fig.4 7 において、温度ごとに回帰分析を行った結果と、校正曲 線はおおむね一致したが、温度ごとに回帰分析を行った結果では含 水率が $30 \%$ を超える付近から、含水率の上昇に伴い温度ごとの電気 抵抗の大小が逆転する箇所が 4 樹種の中で 3 箇所見られた。原因と して高含水率領域では誤差が増える可能性や、計測点が不足してい る可能性が考えられる。校正曲線では係数 a,b,c,d を温度の一次関 数としているため、電気抵抗の大小は逆転しない。また、校正曲線 の決定係数は最低でもべイマツ・ $90^{\circ} \mathrm{C}$ 時の 0.84 と、係数 a,b,c,d を 温度の一次関数とした場合でも高い相関性を示した。

常温時の校正曲線の電気抵抗は、含水率 $15 \%$ ではスギが最も高く $\ln (\mathrm{R})=18.2$ であるのに対し、含水率 $100 \%$ ではスギが最も低く $\ln (\mathrm{R})=12.4$ となり、スギが他の 3 樹種に比べ含水率上昇に対する電 気抵抗の低下が大きくなっている。9 $90^{\circ} \mathrm{C}$ 校正曲線についても同様 で、含水率 $15 \%$ ではスギが $\ln (\mathrm{R})=12.3$ と最も高く、含水率 $100 \%$ で はスギが $\ln (\mathrm{R})=10.4$ と最も低くなった。校正曲線の $100^{\circ} \mathrm{C}$ 以下の範 囲で最も電気抵抗が低くなったのは、 $90^{\circ} \mathrm{C}$ 時のケヤキで、 $\ln (\mathrm{R})=8.9$ となった。

\section{3 含水率の算出}

電気抵抗と含水率の関係は、電気抵抗を求める(2)式において回帰 分析を行ったため、含水率を求めるためには逆関数に直す必要があ る。含水比から電気抵抗を求める(2)式を、電気抵抗から含水比を求 める逆関数に直し、係数を整理すると(4)式で表すことができる。た だし、式を簡単にするため、定数項をまとめて $\alpha$ とている。

$$
\mathrm{u}=\alpha-\frac{\mathrm{w}\left[\frac{\mathrm{cd}}{\mathrm{b}} \exp (\alpha \mathrm{d})\right]}{\mathrm{d}} \quad \text { where } \quad \alpha=\frac{\ln (\mathrm{R})-\mathrm{a}}{\mathrm{b}}
$$

$\mathrm{W}[\mathrm{y}]$ : Lambert W function

(inverse function of $\mathrm{x} \cdot \exp (\mathrm{x})=\mathrm{y} \quad$ )

(4)式を用いて含水率を算出するためには、まず含水率計を設置し た箇所と同等の温度 $\mathrm{T}\left[{ }^{\circ} \mathrm{C}\right]$ を Table 2 に代入し、係数 $\mathrm{a}, \mathrm{b}, \mathrm{c}, \mathrm{d}$ を算出 する。算出した係数 $a, b, c, d$ と、計測した電気抵抗の自然対数 $\ln (\mathrm{R})$ を(4)式に代入することで含水比 $\mathrm{u}[-]$ を得る。含水比 $\mathrm{u}[-]$ を百分率に 直すことで、一般的に用いられる含水率[\%]となる。

\section{4 含水率計の適用可能性}

\subsection{1 計測可能範囲}

Fig.4 7 を見ると、木材の電気抵抗は含水率が低ければ含水率の 低下に対して指数的に増加し、含水率が高ければ含水率の変化に対 する変化が小さくなる。そのため、計測可能な含水率の下限は電気 抵抗の計測上限で決まり、本実験では、使用したデータロガーで計

測のできる抵抗の上限が約 $10 \mathrm{G} \Omega$ であることから、 $\ln (\mathrm{R})=23.0$ が 計測上限となる。樹種、温度により異なるが、含水率が約 $10 \%$ 以下 で計測が不可能となる。一方、含水率が大きいと電気抵抗の変化が 小さくなって、誤差が増加して正確な計測が困難となる。

Fig.8 11 に、樹種ごとの含水率と校正曲線から算出した含水率の 誤差を示す。誤差は、計測した電気抵抗及び温度から校正曲線を用 いて含水率を算出し、その值から、電気抵抗計測後に全乾法で求め た含水率を引いた值を示している。すなわち、縦軸上側が校正曲線 による計算值が実際の含水率よりも高く算出されていることを示す。

また、グラフ中の折線は、温度の影響は考えず樹種ごとに、含水 率をそれぞれ 20\%以下、20～30\%、30～40\%、40～50\%、50\%以上 の 5 グループに分け、それぞれのグループについて標準偏差と平均 含水率を算出し、標準偏差の 2 倍值を正負にプロットして結んだも のを示す。折線で囲まれた領域に $95 \%$ 以上の確率で校正曲線による 計算值が入ること意味している注 2$)$ 。本研究では、含水率のグループ 分けを温度ごとに行うと、計測点が不足し標準偏差を算出できない グループが生じたため、温度の影響は考えずに標準偏差を算出した。 ただし、スギについては全ての温度条件の計測点を含めても含水率 $30 \sim 50 \%$ の間に計測值が 2 点しか得られなかったため、含水率 $20 \%$ 以下、20 30\%、30\%以上の 3 グループから算出した值をプロット した。

含水率 $15 \%$ では、標準偏差の 2 倍值は、スギ $0.9 \%$ 、カラマツ $1.5 \%$ 、 ベイマツ及びケヤキが 1.6\%である。ノルウェイスプルースの常温時 の校正曲線から求められた標準偏差の 2 倍値は、含水率 $15 \%$ 時に約 $1.2 \%$ であり 15$) 、$ 気乾状態付近の精度は大差ない。

含水率が計測可能な上限は、樹種により含水率の増加に伴う誤差 の増加傾向が異なるため、樹種と目標とする精度により異なると考 えられる。例えば標準偏差の 2 倍值を $5 \%$ まで許容した場合では、 計測可能な含水率の上限は、スギは $33 \%$ 、カラマツ、ベイマツ及び ケヤキは $27 \%$ となり、火災加熱により含水率がこれらの值を超えて 上昇した場合誤差はさらに増大していくこととなる。

含水率 $50 \%$ 時の標準偏差の 2 倍值は、スギが最も低く $10.1 \%$ に対 し、常温時のノルウェイスプルースでは $5.3 \%$ となている ${ }^{15)}$ 。本 研究では高温時の電気抵抗を含めて校正曲線を算出しているが、気 乾状態では常温時のノルウェイスプルースと比べても誤差に大きな 差はないことから、高温・高含水率状態での電気抵抗測定において 誤差が増大したこととなる。原因として試験体が高温であることに より、試験体切断時の水分蒸発や、含水率計近傍の直方体内部の含 水率分布にばらつきが生じた可能性が挙げられる。予め含水率分布 を均一とした試験体の電気抵抗を計測し、切断せずに質量を計測す れば、高温・高含水率状態の誤差を小さくできる可能性があるが、 試験体数は増大寸ることとなる。また、含水率 $50 \%$ 時の標準偏差の 2 倍值は、ケヤキ、カラマツ、ベイマツ、スギと全乾密度の高い順 に大きくなっている。含水率は全乾密度を分母に算出しているため、 全乾密度が大きいほど含水量自体は多いこととなり、そのことが誤 差が大きくなる要因となっている可能性がある。

\subsection{2 火災加熱を受ける木材を想定した含水率の計測精度}

火災時における木質部材内部の含水率を計測する主な目的は、力 学的性能、及び炭化速度や燃焼性状一の含水率の影響を明らかにす ることにある。含水率がこれらの性質に影響を与える含水率の範囲 
はそれぞれ異なるため、計測目的によって含水率計測に求められる 計測可能範囲と精度が異なってくると考えられる。

まず、力学的性能に木質部材内部が高温・高含水率状態となるこ とがどう影響するかを考えると、含水率 $30 \%$ 以上では高温時の力学 的性能は含水率にほぼ依存しなくなる $\left.{ }^{4}\right)$ から、含水率の把握は $30 \%$ 以下の範囲で最も重要である。加熱前の状態から含水率が増減する 過程を計測するためには、加熱前の状態で含水率を計測できている 必要があるが、加熱前の状態を気乾状態とすると、含水率 $15 \%$ で標 準偏差の 2 倍值は、ベイマツ及びケヤキが最大で $1.6 \%$ あるる。

加熱により含水率が低下寸る場合、含水率の低下に伴い誤差は減 少する。ただし、含水率の低下に伴い電気抵抗は上昇するため、装 置の計測可能な電気抵抗を上回ると計測ができなくなり、その限界 は含水率約 $10 \%$ であ。火災加熱により気乾状態から含水率が上昇 する場合、含水率 $20 \%$ 時の標準偏差の 2 倍值は、スギ及びカラマツ は $1.8 \%$ 、ベイマツは $2.6 \%$ 、ケヤキは $2.8 \%$ と最大でも $3 \%$ 以内に収 まっている。よって、気乾状態から含水率が上昇する過程は含水率 $20 \%$ ま゙は高い精度で計測することが可能と考えらえる。ただし、 断面が四周から加熱され中央に水分が集中寸る場合や炭化して高温 となる領域に対して残存断面が小さい場合は比較的含水率が上昇し やすいと考えられる。20\%を超えてさらに含水率が上昇した場合、 含水率の増加に伴い誤差は増加するため、樹種や目標とする計測精 度によっては正確な計測が困難となると考えられる。

また、人工乾燥された集成材や小断面の製材等であれば、加熱前 の含水率は気乾状態程度であると考えられるが、大断面製材のよう に内部の含水率分布が不均一で、加熱前から気乾状態よりも含水率 が高い場合も考えられる。例えば、ケヤキの大断面製材の含水率が $30.4 \%$ であった例があり 8)、ケヤキの標準偏差の 2 倍值は含水率 $30 \%$ 時に $8.9 \%$ と、加熱前から誤差が大きい。その場合、電気抵抗と温度 の変化から相対的に含水率の変化を算出することは可能だが、正確 な含水率を得られない可能性が高いと考えられる。

一方、炭化速度や燃焼性状は含水率が $30 \%$ 以上でも含水率の影響 を受ける 2),6 (8) ため、高含水率領域においても含水率が測定できる ことが望ましい。しかし、高含水率領域では含水率の変化に対する 電気抵抗の変化が小さい 15),16) ことが知られており、本研究において も含水率上昇に伴い誤差が増大している。含水率 $50 \%$ 時の標準偏差 の 2 倍值は、スギが最小で $10.1 \%$ 、ケヤキが最大で $30.1 \%$ となって いる。このように、高含水率領域における含水率測定は、電気抵抗 から算出すると誤差が大きく、含水率の大小に精度が左右されない
別の手法が適していると考えられる。木材の質量と関係なく存在す る常温時の水分量のみを計測できる手法としては、二重 X 線による 計測手法 ${ }^{20)}$ があり、今後計測原理を活用し高温下で計測が可能とな れば、含水率に精度が依存せず計測ができる可能性がある。

\section{5 計測精度への樹種・温度の影響 \\ 4.5.1 校正曲線における支配率の定義}

本含水率計測における計測精度への樹種・温度の影響を検証する ため、樹種ごとの校正曲線における係数 a,b,c,d と温度の関係をそ れぞれ Fig.12 15 に示す。

(2)式における係数 $a, b, c, d$ と電気抵抗の変化の関係について、電 気抵抗の変化は定数である $\mathrm{a}$ には影響を受けず、第二項 $\mathrm{b} \mathrm{u}$ 及び第 三項 $\mathrm{c} \exp (\mathrm{d} \mathrm{u})$ により変化する。以下、第二項 $\mathrm{b} \mathrm{u}$ を線形項、第 三項 $\mathrm{c} \exp (\mathrm{d} \mathrm{u})$ を指数項と呼ぶ。指数項は、d が負の值を取ること から、含水率上昇に伴い、比較的低含水率となる領域では指数的に 電気抵抗が減少し、高含水率となる領域では電気抵抗の変化が緩や かに 0 に近づいていくことを表す項である。つまり、低含水率領域 では指数項が支配的となり高含水率領域では線形項が支配的になる と考えられる。含水率上昇によって指数項の変化が小さくなると、 含水率変化時の電気抵抗の応答が減少し、計測精度が低下寸ると考 えられる。そのため、力学的性能に影響する低含水率領域において、 指数項が支配的である境界を調べるため、(5)式で指数項の支配率を 定義する。指数項の支配率は(2)式において含水率が $1 \%$ 上昇した際 の $\operatorname{In}(\mathrm{R})$ の変化のうち指数項の変化の割合を示す(以下、本文中では 「支配率」と略す)。(5)式の $\Delta \mathrm{c} \exp (\mathrm{d} \mathrm{u})$ 及び $\Delta \mathrm{b}$ u はいずれも負の 值であるが、校正曲線においては含水率変化時の電気抵抗の応答の 大きさを表すため、絶対值を取り正の值で表現した。

指数項の支配率 Dominant ratio of exponential term

$$
=\frac{|\Delta \mathrm{cexp}(\mathrm{d} \mathrm{u})|}{|\Delta \ln (\mathrm{R})|}=\frac{|\Delta \mathrm{cexp}(\mathrm{d} \mathrm{u})|}{|\Delta \mathrm{bu}|+|\Delta \mathrm{cexp}(\mathrm{d} \mathrm{u})|}
$$

\section{$|\Delta y|:$ 含水率 $1 \%$ 上昇時の各項の変化量} change of y by $1 \%$ increase of moisture content

\subsection{2 樹種・温度による支配率の差異と計測精度への影響}

含水率が木材の力学的性能に及ぼす影響を検討する必要のある上

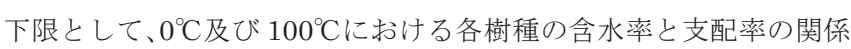
を Fig. 16 に示す。実線で $0^{\circ} \mathrm{C}$ 、点線で $100^{\circ} \mathrm{C}$ における支配率を示し

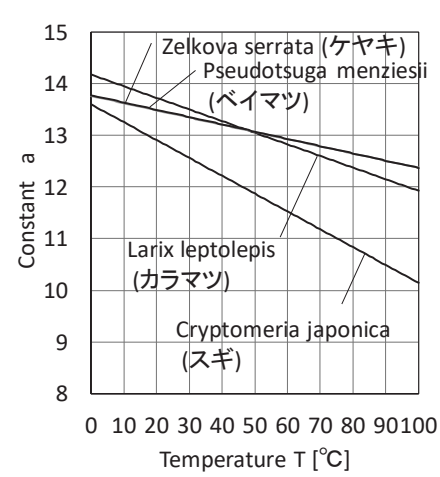

Fig.12 Temperature vs. const. a

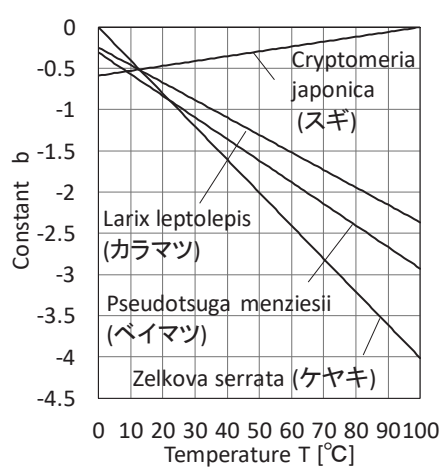

Fig.13 Temperature vs. const. b

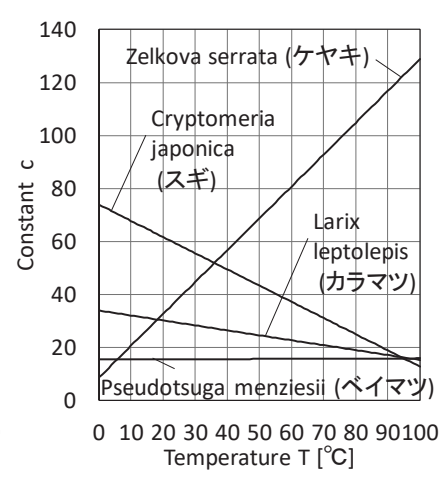

Fig.14 Temperature vs. const. c

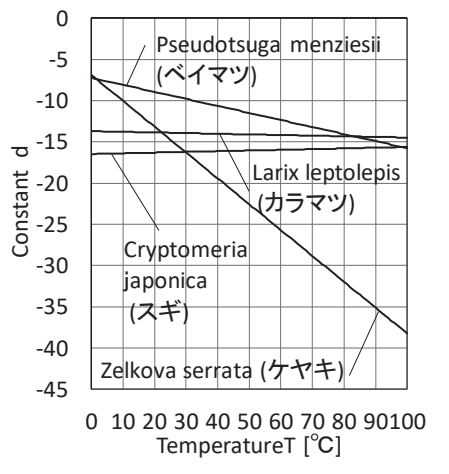

Fig.15 Temperature vs. const. d 
ている。係数 $\mathrm{b}$ はどの温度でも 0 以下となるように回帰分析をして おり、スギは $100^{\circ} \mathrm{C}$ 、ケヤキは $0^{\circ} \mathrm{C} て ゙ ~ 0$ となり、支配率は 1 で一定 となった。

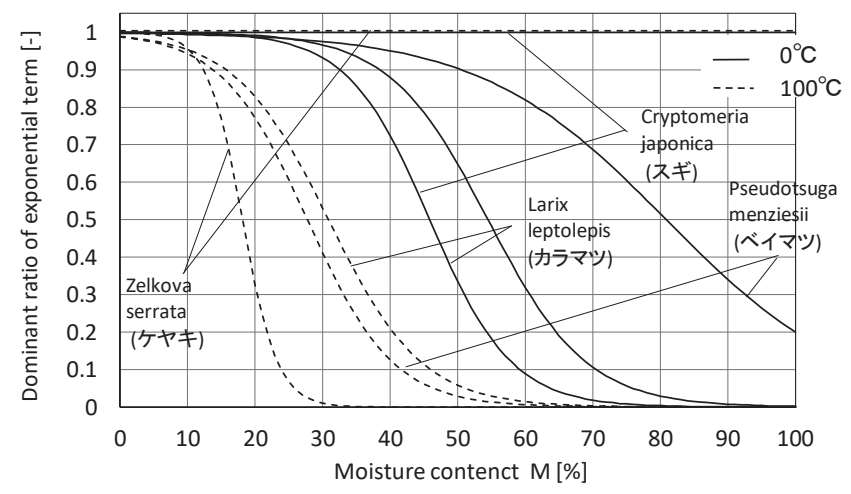

Fig.16 Moisture content vs. dominant ratio of exponential term in Equation (5)

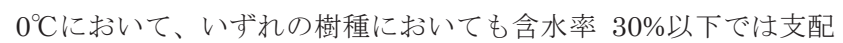
率が 0.9 を超えている。このことは、支配率が高いことは誤差が少 ないことを意味すると考えると、4.4 節における比較的低含水率の 領域では誤差が少ないという考察と合致する。

$0^{\circ} \mathrm{C}$ と比較して $100^{\circ} \mathrm{C}$ では、スギを除いて、比較的低含水率から支 配率が減少し、含水率 $30 \%$ で約 0.5 以下となっている。温度上昇に より支配率が減少する要因は、(5)式における線形項の変化量の増加、 及び指数項の変化量の減少である。線形項においては、係数 $\mathrm{b}$ の減 少に伴い変化量が増加する。指数項においては、係数 $\mathrm{c}$ が減少する と変化量は減少し、係数 $\mathrm{d}$ が減少すると校正曲線は下に凸となり、 低含水率領域での電気抵抗の減少が著しくなる。よって、温度上昇 による低含水率領域の指数項の支配率の減少は、係数 b,c,d の減少 に起因する。ただし、係数 b,c,d はそれぞれが独立した温度との関 数であり、3つの係数が同時に減少または増加するとは限らないた め、樹種ごとに係数 b,c,d の温度依存性と支配率への影響について 考察を行う。

スギは、Fig.16 において温度上昇に伴い支配率は増加している。 温度上昇に伴い係数 $\mathrm{b}$ は増加、係数 $\mathrm{c}, \mathrm{d}$ は減少していることから、 係数 b のみが温度上昇に伴い支配率が上昇する傾向を有している。 スギの係数 b は、Fig. 12 に示すように温度上昇に伴い増加し $100^{\circ} \mathrm{C}$ で 0 になることから、線形項の変化量が極小化していき、支配率が 増加したと考えられる。ただし、温度上昇に伴い係数 c, d は減少し ていることから指数項の変化量も減少しており、線形項と指数項の 双方の変化量が減少している。よって、温度上昇に伴い低含水率領 域における含水率変化時の電気抵抗の応答は低下している。支配率 の増加が線形項の極小化に起因する場合は、支配率の上昇が計測精 度の増加を意味するとは限らないと言える。

カラマツ、ベイマツ及びケヤキは、Fig.16において温度上昇に伴 い支配率は減少している。カラマツ及びベイマツについては、カラ マツの係数 $\mathrm{d}$ とベイマツの係数 $\mathrm{c}$ は温度によらずほぼ一定であり、 その他の係数は温度上昇により減少しているため、支配率が温度上 昇により減少したと考えられる。ケヤキについて、温度上昇に対し
て係数 $\mathrm{d}$ は減少、係数 $\mathrm{c}$ は増加寸るが、支配率は温度上昇により減 少している。特に係数 $\mathrm{c}, \mathrm{d}$ の温度上昇による変化は他の樹種に比べ て著しい。係数 $\mathrm{d}$ の減少に伴い高含水率領域での含水率の変化がほ とんど見られなくなり、係数 $\mathrm{c}$ が増加しても支配率に影響しなかっ たものと考えられる。Fig. 15 において、係数 $\mathrm{d}$ の $0^{\circ} \mathrm{C}$ から $100^{\circ} \mathrm{C} の$ 変化はケヤキ、ベイマツ、カラマツの順に大きいが、Fig.16におけ る $0^{\circ} \mathrm{C}$ から $100^{\circ} \mathrm{C}$ 支配率の変化も、係数 $\mathrm{d}$ の変化と同じ順に大き く、係数 $\mathrm{d}$ が支配率の変化に大きく影響すると考えられる。

以上より、校正曲線は力学的性能に影響する低含水率領域におい て、低温時には樹種によらず指数項が支配するが、温度上昇による 指数項の支配率の増減は樹種により異なった。力学的性能の含水率

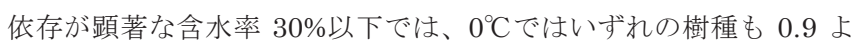

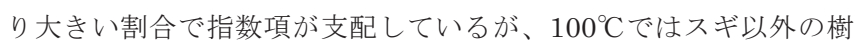
種では支配率が 0.5 以下に減少した。スギについても、支配率の温 度上昇による増加は線形項の極小化に起因しており、温度変化に対 する電気抵抗の変化は減少していることとなった。よって、いずれ の樹種においても、低含水率領域において、含水率に対する電気抵 抗の応答は高温時になると低下寸る傾向を有寸ることが明らかとな った。今後、温度ごとの誤差の違いを検証する必要があるが、本研 究では計測点数の不足から温度によらず校正曲線の誤差を算出して いるため、計測点数を増す必要がある。

また、校正曲線の係数の温度依存性は本研究で計測を行った 4 樹 種で異なった。心材・辺材、早材・晚材、及びそれらによる密度の 差異は電気抵抗に影響しないこと ${ }^{15}$ )から、これら 4 樹種間の差異は 試験体ごとのばらつきではなく、樹種の違いによると考えられる。 よって、本研究で検討していない樹種に本測定法を適用する場合に は改めて校正曲線を得ておく必要がある。

\section{5 総括}

本研究では、加熱実験時の木質部材の任意の箇所に設置し、内部 の含水率の時間変化を計測できる含水率計の開発を行った。含水率 計の計測原理は、木材内部の計測位置における電気抵抗及び温度を 計測し、含水率を校正曲線から逆算するものであり、以下の成果と 知見を得た。

（1）耐熱性を有する装置を開発し、電気的な絶縁を計測部まで保ち 配線できるようにした。木材内部に埋め込む電極近傍の耐熱温度、 及び配線に用いた絶縁導線の耐熱温度は $150^{\circ} \mathrm{C}$ となり、大気圧付近 では、含水率の計測に支障なく使用できる。

(2) スギ、カラマツ、ベイマツ及びケヤキを対象に $20^{\circ} \mathrm{C}$ から $90^{\circ} \mathrm{C} て ゙$ 電気抵抗と含水率の関係を計測した。電気抵抗は低含水率領域では 含水率の上昇に伴い指数的に減少し、いずれの樹種でも含水率及び 温度の上昇に伴い電気抵抗は減少した。計測結果から回帰分析を行 い、電気抵抗及び温度から含水率を算出する校正曲線を樹種ごとに 導出した。

（3）提示した含水率測定法で計測可能な下限は約 $10 \%$ 、上限は樹種 や要求精度により異なるが、含水率 $20 \%$ で誤差は最大 $2.8 \%$ となっ た。従って、高温時の力学的性能に影響する比較的低含水率の領域 に関して、気乾状態付近から含水率が減少、または増加する過程を 計測することが可能となった。一方、高含水率となる領域では、含 水率の変化に対する電気抵抗の変化が減少するため誤差が増加し、 
発熱速度や熱容量への含水率の影響を調查する際は計測精度が不十 分となる可能性がある。

（4）校正曲線は、高温時になると低含水率領域における含水率変化 に対する電気抵抗の応答が減少する傾向があり、温度上昇に伴い低 含水率領域の計測精度が低下している可能性がある。

（5）校正曲線を定める係数の温度依存性は樹種ごとに異なり、本研 究で校正曲線を得ていない樹種について含水率計を用いる場合は校 正曲線を新たに得る必要がある。

今後の課題として、計測手法の妥当性の検証や木質部材内部で起 こる熱水分移動の予測モデルの確立を進めるために、熱・物質移動 に関する境界条件を単純化できる定常加熱下で含水率分布の変化を 実測し、絶乾法により求めた含水率分布や木材中の熱水分移動モデ ルから予想される状況と比較することが必要である。火災加熱時の 木質部材内部の含水率の力学的性能への影響を評価するためには、 耐火炉内で実際の火災を想定した加熱下における含水率分布の変化 を計測する必要があり、そのための測定方法の改良も課題である。

\section{謝辞}

本研究内の実験は、科学研究費基盤研究「大断面木質部材の防耐 火性能設計の工学モデル」及び「大規模居室における内装の燃焼拡 大性状の予測と火災規模の局限化に関する研究」(ずれも代表研究 者: 長谷見雄二)の一環として行いました。試験体製作には、共同組 合遠野グルーラムの菊池和貴氏に甚大なるご協力を賜りました。含 水率計の開発にあたり、飯島泰男氏(秋田県立大学名誉教授)、原田和 典氏(京都大学教授)、田中孝氏(静岡大学助教)、遠藤智紀氏(当時、早 稲田大学大学院)、渡辺秀太氏 (当時、早稲田大学大学院)、その他様々 な方々に貴重なご助言、ご協力を賜りました。記して深く感謝申し 上げます。

\section{参考文献}

1) Forest Products Laboratory : Wood Handbook,pp.5-36,2010

2) Naruse, T. Nakamura, K. Yusa, S. Masuda, H. Harada, T. Yamada, M. Sato, A.: Fire Resistance of Structual Timber Part $1:$ Charring Rate of Cedar and Larch, Summaries of Technical Papers of Annual Meeting, Architectural Institute of Japan, A-2, pp.11-12, 2004.7 (in Japanese) 成瀬友宏, 中村賢一, 遊佐秀逸, 増田秀昭, 原田寿郎, 山田誠, 佐藤章 : 構造用製 材の耐火性能 その 1 : スギとカラマツの炭化速度, 日本建築学会大会学術 講演梗概集,A-2, pp11-12, 2004.7

3) Kaku, C. Hasemi, Y. Yasui, N. Yasukawa, M. Kamikawa, D. Kameyama, N. Ono, T. Koshihara, M. and Nagao, H.: Influence of Fire Exposure on the Mechanical Properties of Wood -Exposure temperature dependence of Young's modulus and bending strength of Cryptomeria japonica, Larix leptolepis,Pseudotsuga menziesii and Zelkova serrata under and after heating-, Journal of Structural and Construction Engineering (Transactions of AIJ), Vol.79, No.701, pp1065-1072, 2014.7 (in Japanese) 加來千紘, 長谷見雄二, 安井昇, 保川みずほ,上川大輔, 亀山直央, 小野徹郎, 腰 原幹雄, 長尾博文 : 火災加熱が木材の力学的性能に及ぼす影響 一加熱した 針葉樹材及び広葉樹材の高温時及び加熱冷却後のヤング係数・曲げ強度の 測定一, 日本建築学会構造系論文集 79 巻 701 号,pp1065-1072,2014.7

4) Suzuki, T. Kaku, C. Hasemi, Y. Kamikawa, D. Yasui, N. Kameyama, N. Koshihara, M. and Nagao, H.: Influence of Water Content on the Mechanical Properties of Wood under Heating Part1: Exposure temperature and Water Content dependence of Young's modulus and bending strength of cedar, Summaries of Technical Papers of Annual Meeting, Architectural Institute of Japan, Fire Safety, pp.135-138, 2015.9 (in Japanese)
鈴木達朗,加來千紘,長谷見雄二,上川大輔,安井昇, 亀山直央,腰原幹雄,長尾博 文：木材の含水率が高温時の力学的性能に及ぼす影響：(その 1)針葉樹材 (スギ)の高温時ヤング係数・曲げ強度の把握, 日本建築学会大会学術講演梗 概集，防火, pp135-138, 2015.9

5) BS EN1995-1-2: 2004, Eurocode 5 Design of timber structures, Part1-2: General-Structural fire design

6) Fredlund, B. : A Model for Heat and Mass Transfer in Timber Structures During Fire, Lund University Sweden, 1985, Ph.D. thesis

7) Kikuchi, S. Kawarasaki, M.: Influence of Density and Moisture Content on Heat Release Properties of Wood, J. Hokkaido For. Prod. Res. Inst., Vol.22, No.2, 2008.3 (in Japanese)

菊地伸一,河原崎政行: 木材の発熱性に対する密度,水分の影響,林産試験場 報,第 22 巻,第 2 号, 2008.3

8) Yasukawa, M. Yasui,N. Suzuki, A, Hasemi, Y. Kameyama, N. Toyoda, K. Kadooka, N. Kamikawa, D. Koshihara, M. and Ono, T.: Experiments for the Verification of the Predict Ability of Structural Fire Resistance of Heavy Hard Wood (Zelkova) Columns, Journal of Structural and Construction Engineering (Transactions of AIJ), Vol.685, pp.633-638, 2013.3 (in Japanese)

保川みずほ,安井昇,鈴木あさ美,長谷見雄二, 亀山直央, 豊田康二, 門岡直也, 上 川大輔,腰原幹雄, 小野徹郎: 大断面広葉樹 (ケヤキ) 製材による軸組柱の防 耐火性能予測に関寸る研究, 日本建築学会構造系論文集 第 685 号,pp.633$638,2013.3$

9) Tanaka, T. : Recent Trend of Scientific Researches and Problems on Understanding and Modeling of Moisture Transport in Wood, Wood Industry, Vol.67, No.6, pp.242-247, 2012.6 (in Japanese)

田中孝: 木材中の水分移動機構の解明とそのモデル化に関寸る近年の研究 動向と課題,木材工業,第 67 巻,第 6 号,pp.242-247,2012.6

10) Suzuki, T. Kaku, C. Kamikawa, D. Yasui, N. Hasemi, Y. Suzuki, J.: Development Research of Water Transfer Measurement Method of Wood under Heating, Summaries of Technical Papers of Annual Meeting, Architectural Institute of Japan, Fire Safety, pp.19-20, 2016.8 (in Japanese)

鈴木達朗,加來千紘,上川大輔,安井昇,長谷見雄二,鈴木淳一: 火災加熱される 木質部材内部の水分移動計測手法の開発研究, 日本建築学会大会学術講演 梗概集，防火, pp19-20, 2016.8

11) Suzuki, T. Kamikawa, D. Yasui, N. Hasemi, Y. Kaku, C. Endo, T. Watanabe, S. Suzuki, J.: Influence for the Mechanical Property of Wood Exposed Fire caused by Water Transfer, Summaries of Technical Papers of Annual Meeting, Architectural Institute of Japan, Fire Safety, pp.353356, 2017.8 (in Japanese)

鈴木達朗,加來千紘,上川大輔,安井昇,長谷見雄二,鈴木淳一: 火災時の木質部 材断面における水分移動状況の把握と力学的性能への影響評価, 日本建築 学会大会学術講演梗概集,防火, pp.353-356,2017.8

12) Wood moisture sensor by high-frequency capacitance: HM520, Manufactured by Kett

http://www.kett.co.jp/ (accessed 2019.4.24.) 高周波容量式木材水分計 : HM520,Kett 製

13) Contact timber moisture meter : LG6NG, Manufactured by LOGICA $\mathrm{H} \& \mathrm{~S}$

https://www.logica-hs.com/en/ (accessed 2019.4.24.)

14) Harada, K. Terai, T. : A Model of Heat and Mass Transfer in Concrete during Fire, Journal of Structural and Construction Engineering (Transactions of AIJ), No.477, pp.185-190, 1995.11 (in Japanese) 原田和典, 寺島俊夫 : 火災時のコンクリート内部の熱水分移動のモデル, 日 本建築学会構造系論文集,477 号,pp185-190,1995.11

15) Fredriksson, M. Wadso L. Johansson, P. : Small resistive wood moisture sensors: a method for moisture content determination in wood structures, European Journal of Wood and Wood Products, Vol.71, Issue 4, pp.515-524, 2013.7

16) Du, Q.P., Geissen, A. Noack, D.: Moisture resistance characteristics of some commercial wood species and their measurability by DC type moisture meters, Holz als Roh-und Werkstoff, Vol.49, pp.305-311, 1991.1 (in Germany)

17) Japan Society of Mechanical Engineers: JSME Data Book Heat Transfer 4th Edition, p315, Maruzen,1986.10 (in Japanese) 
日本機械学会 : 伝熱工学資料 改訂第 4 版,p315,丸善 1986.10

18) Epoxy Technology Inc. : Data Sheat of E4110

http://www.epotek.com/site/administrator/components/com_products/as sets/files/Style_Uploads/E4110.pdf （accessed 2019.4.24.)

19) Ogura, T. Onuma, K.: On the computation of moisture distribution in wood by means of electric resistance, Research Report of Forestry and Forest Products Research Institute, Vol.53, pp.83-101, 1952.7 (in Japanese)

小倉武夫,大沼加茂也 : 電気抵抗による木材水分分布の推定について,森林総 合研究所研究報告,第 53 号,pp83-101,1952.7

20) Tanaka, T.: Evaluation of solid wood moisture content based on dualenergy X-ray absorptiometry, Wood industry, Vol.70, No.3, pp132-135, 2015.3. (in Japanese)

田中孝: 実験講座(23)二重エネルギーX 線吸収法による木材の含水率測定, 木材工業第 70 号,第 3 巻,pp132-135,2015.3

注

注 1）木材の電気抵抗を、今回計測している電気抵抗の下限值よりも明らかに 低い $\ln (\mathrm{R})=8[\Omega]$ 、寸なわち約 $3000[\Omega]$ とする。今回用いたニッケル線を $100 \mathrm{~m}$ 、電気抵抗率を $300[\mathrm{~K}]$ で $7.6[\mu \Omega \cdot \mathrm{cm}] 、 600[\mathrm{~K}]$ で $25.3[\mu \Omega \cdot \mathrm{cm}]$ と すると ${ }^{17)}$ 、電気抵抗はそれぞれ $0.076[\Omega] 0.25[\Omega]$ となる。電線と木材の合 成抵抗に反比例して電流が流れるとすると、ニッケル線の電気抵抗の変化 は合成抵抗に対して $0.1 \%$ 以上ななる。

注 2）正規分布を仮定した場合、一般的に $95 \%$ の信頼区間は標準偏差の 1.96 倍を用いて算出される。本研究の含水率計は、常温下での計測を前提とし

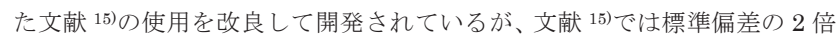
值を用いている。本研究においても、文献 15) と誤差を比較するため、及び 1.96 倍よりも大きな值であれば誤差を過少評価することにならないため、 標準偏差の 2 倍值を用いた。 


\title{
DEVELOPMENT OF DYNAMIC MOISTURE CONTENT MEASUREMENT SYSTEM FOR WOODEN MEMBERS EXPOSED TO FIRE HEATING
}

\author{
Tatsuro SUZUKI*1, Yuji HASEMI*2, Daisuke KAMIKAWA*3, \\ Noboru YASUI*4, Chihiro KAKU ${ }^{* 4}$ and Jun-ichi SUZUKI*5 \\ ${ }^{* 1}$ Technology Center, Taisei Corp., M.Eng. (Formerly, Waseda Univ.) \\ *2 Prof., Faculty of Science and Engineering, Waseda Univ., Dr.Eng. \\ ${ }^{* 3}$ Forestry Research and Management Organization, Ph.D. \\ ${ }^{* 4}$ Adjunct Researcher, RISE Waseda Univ., Ph.D. \\ ${ }^{* 5}$ National Institute for Land and Infrastructure Management, Ph.D.
}

A small sensor for the dynamic measurement of local moisture content within a wooden member exposed to fire heating is developed. Time variation of local moisture content of a wooden member during fire tests has not been grasped for the lack of non-destructive measurement system suitable for high temperature. This work intends to develop a heat resistive small sensor applicable to wooden specimen for fire tests to make it possible to monitor the distribution and time variation of moisture content within a wooden specimen just as thermocouples commonly used for the measurement of the distribution and time variation of temperature of a specimen.

Importance of the measurement of local moisture content of a wooden specimen during fire tests comes from the recent advance in the recognition of the importance of moisture content in the high temperature performance of wood, e.g. significant influence of moisture content on the mechanical properties especially at high temperature and on the thermal decomposition as well as for the possible significant transfer of water within heated porous material such as wood due to the vaporization and re-condensation during fire. The possible influence of moisture content of wood may affect not only the charring rate of load bearing members but ignition and flame spread above wood based interior surface.

The proposed measurement system is based on the unique dependence of electric resistance of wood on the moisture content and temperature. The present work consists of the design of a small heat resistant electrical resistance sensor and the development of calibration curves by experiments for the correlation of electrical resistance against temperature and moisture content for most typical tree species for building construction: Cryptomeria japonica, Larix leptolepis, Pseudotsuga menziesii and Zelkova serrata are chosen. Main results as follows.

First, the specifications of the heat resistant sensor are shown in Fig.1, which essentially monitor the electric resistance between the couples of the wires. Copper wire reported in a previous work for the measurement at room temperature (Fredriksson et al, 2013 ) is replaced by electrically insulated nickel wire for the improvement of heat resistance. The upper temperature limit of electrodes the proposed sensor is $150^{\circ} \mathrm{C}$; electrically insulated wires need to be wired not to be exposed to temperature higher than $150^{\circ} \mathrm{C}$ during measurement.

Second, the proposed sensors are applied to wooden plate specimens with the moisture content gradient from $6.9 \%$ to $232.8 \%$ conditioned at test temperatures from $20^{\circ} \mathrm{C}$ to $90^{\circ} \mathrm{C}$, for the determination of the relationship between electrical resistance and moisture content at each test temperature. The specimen was cut after the test to take samples around each sensor couples to confirm the moisture content by comparing the weight before and after drying. Relations between electric resistance and moisture content are found to differ for tree species.

Finally, the measurement is found to be most effective within the moisture content $10 \%-30 \%$ : below the lower limit, about $10 \%$, electric resistance rises rapidly with decrease of moisture content, while above the upper limit electric resistance becomes insensitive to moisture content.

In the future, time variation of local moisture content of wooden specimens under steady heating should be measured with the proposed sensors and measurement results should be compared with actual distributions of moisture content calculated from bone-dry weight to verify the validity of the measurement system and improve the prediction of heat and water transfer. Time variation of local moisture content of wooden members during fire furnaces test need to be measured with the sensor to evaluate influence of moisture content on mechanical properties. 